\title{
Catalytic Enantioselective Synthesis of Sulfinate esters Throught the Dynamic Resolution of tert-Butanesulfinyl Chloride
}

Jared W. Evans, Jonathan A. Ellman ${ }^{* *}$ and Matthew B. Fierman, Scott J. Miller*E

${ }^{\dagger}$ Center for New Directions in Organic Synthesis, Department of Chemistry, University of California, Berkeley, California 94720 ¿Department of Chemistry, Boston College, Chestnut Hill, MA 02467

\section{Supporting Information}

Reagents and General Methods. Unless otherwise noted, all materials were obtained from commercial suppliers and used without further purification. All solvents were distilled under $\mathrm{N}_{2}$ from the following drying agents immediately before use: tetrahydrofuran (THF) and ether were distilled from sodium/benzophenone ketyl, and dichloromethane $\left(\mathrm{CH}_{2} \mathrm{Cl}_{2}\right)$, methanol $(\mathrm{MeOH})$, toluene, triethylamine $\left(\mathrm{Et}_{3} \mathrm{~N}\right)$, and diisopropylethylamine (Hunig's base) were distilled from $\mathrm{CaH}_{2}$. Unless otherwise noted, all reactions were carried out in flame-dried glassware under an inert $\mathrm{N}_{2}$ atmosphere. Chromatography was carried out using Merck $60 \AA 230-400$ mesh silica gel. Reaction progress was monitored with thin-layer chromatography on Merck $60 \mathrm{~F}_{254} 0.25 \mu \mathrm{m}$ silica plates. Unless otherwise specified, extracts were dried over $\mathrm{MgSO}_{4}$ and solvents were removed using a rotary evaporator under vacuum. Enantiopurities were determined by HPLC using a Daicel CHIRACEL OD column $(4.6 \times 250 \mathrm{~mm})$ with UV detection at 210 and $254 \mathrm{~nm}$. Melting points were determined in open Pyrex capillaries and are uncorrected. IR spectra were recorded using $\mathrm{KBr}$ pellets or $\mathrm{NaCl}$ plates and only partial data are reported. NMR spectra were obtained in $\mathrm{CDCl}_{3}$ at room temperature. Chemical shifts in NMR spectra are expressed in parts per million and all coupling constants are expressed in hertz. Optical rotations were measured on a Perkin-Elmer Model 241 polarimeter. 
Stoichiometric Base and Solvent Selection. A thorough study of base and solvent choice was undertaken to eliminate any background sulfinyl transfer reaction. Examination of sulfinyl transfer using benzyl alcohol and four tertiary amine bases was performed. Using $\mathrm{Et}_{3} \mathrm{~N}$ as the stoichiometric base, a fast background reaction was observed with complete conversion to the benzyl sulfinate occurring within 5 min at -78 ${ }^{\circ} \mathrm{C}$ (entry 1). Employing the more sterically encumbered bases $i-\operatorname{Pr}_{2} \mathrm{EtN}$ and 1,2,2,5,5 pentamethylpiperidine (PEMP) also resulted in significant background reactions (entries 2 and 3 ). Evaluation of 2.5 equiv of proton sponge (1,8-bis (dimethylamino)

naphthalene) resulted in an undetectable background reaction after $40 \mathrm{~h}$ at $-78{ }^{\circ} \mathrm{C}$ in all solvents except $\mathrm{CH}_{2} \mathrm{Cl}_{2}$ (entries 4-7).

Tertiary amine base promoted background reaction

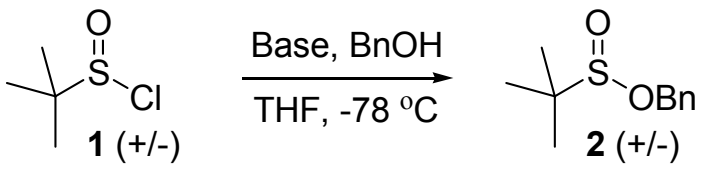

\begin{tabular}{lllllc}
\hline entry & solvent & base & equiv & time & yield $(\%)^{a}$ \\
\hline 1 & $\mathrm{THF}$ & $\mathrm{NEt}_{3}$ & 1.5 & $<5 \mathrm{~min}$ & 98 \\
2 & $\mathrm{THF}$ & $i$-Pr ${ }_{2} \mathrm{EtN}$ & 1.5 & $20 \mathrm{~h}$ & 37 \\
3 & $\mathrm{THF}$ & PEMP & 1.5 & $20 \mathrm{~h}$ & 32 \\
4 & $\mathrm{THF}$ & proton sponge & 2.5 & $40 \mathrm{~h}$ & $<2$ \\
5 & $\mathrm{Ether}$ & proton sponge & 2.5 & $40 \mathrm{~h}$ & $<2$ \\
6 & $\mathrm{CH}_{2} \mathrm{Cl}_{2}$ & proton sponge & 2.5 & $40 \mathrm{~h}$ & 27 \\
7 & Toluene $^{2}$ & proton sponge & 2.5 & $40 \mathrm{~h}$ & $<2$ \\
\hline \multicolumn{4}{l}{ a) Yields determined by NMR with comparison to 2,6-dimethoxytoluene as an internal standard. }
\end{tabular}

\footnotetext{
Alcohol Screen. We examined the effect of a variety of alcohol nucleophiles on sulfinyl transfer with catalyst 5. Faster rates and higher selectivities were generally observed when THF was employed as the solvent, with the greater solubility of alcohols in THF likely contributing to the superior rates. Electronic properties of the alcohol have a
} 
significant effect on selectivity. While para-methoxybenzyl alcohol provided the sulfinate ester in $78 \%$ ee (entry 2), which is comparable to $\mathrm{BnOH}(80 \%$ ee), use of the electron poor para-nitrobenzyl alcohol resulted in decreased enantioselectivity (entry 3). The overall steric properties of the alcohol also had moderate effects on selectivity as can be seen in entries 4-6.

Alcohol screen with peptide catalyst $\mathbf{5}$.
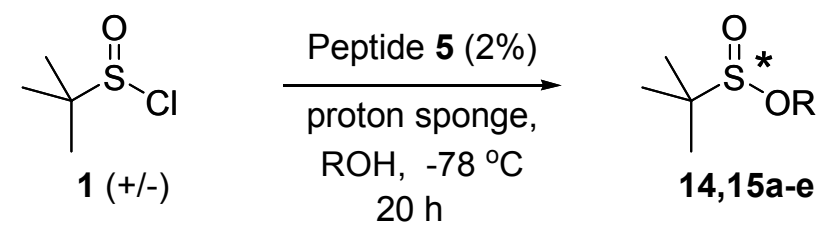

\begin{tabular}{|c|c|c|c|c|c|}
\hline entry & compound & alcohol & solvent & yield $(\%)^{a}$ & ee $(\%)^{b}$ \\
\hline \multirow[t]{2}{*}{1} & 14 & & Toluene & 96 & 58 \\
\hline & & & THF & 99 & 79 \\
\hline \multirow[t]{2}{*}{2} & $15 a$ & & Toluene & 26 & 67 \\
\hline & & & THF & $>99$ & 78 \\
\hline \multirow[t]{2}{*}{3} & $15 b$ & & Toluene & 21 & 56 \\
\hline & & & THF & 67 & 68 \\
\hline \multirow[t]{2}{*}{4} & $15 c$ & & Toluene & 66 & 20 \\
\hline & & & THF & $>99$ & 68 \\
\hline \multirow[t]{2}{*}{5} & $15 d$ & & Toluene & 52 & 52 \\
\hline & & & THF & 56 & 76 \\
\hline \multirow[t]{2}{*}{6} & $15 e$ & & Toluene & 11 & 26 \\
\hline & & & THF & 83 & 73 \\
\hline
\end{tabular}

a) Yields determined by NMR with comparison to 2,6-dimethoxytoluene as an internal standard. b) Enantiomeric excess determined by chiral HPLC.

tert-Butylsulfinyl chloride (1): Hydrogen peroxide $(24.0 \mathrm{~mL}, 252 \mathrm{mmol}$, as a $30 \%$ aqueous solution) was added to a solution of di-tert-butyl disulfide $(36.0 \mathrm{~mL}, 202$ 
mmol) in acetic acid $(200 \mathrm{~mL})$, and the solution was stirred at $4{ }^{\circ} \mathrm{C}$ for $18 \mathrm{~h}$. The reaction solution was poured over ice water, and extracted with $\mathrm{CH}_{2} \mathrm{Cl}_{2}(2 \times 120 \mathrm{~mL})$. The combined organic layers were washed with $\mathrm{NaHSO}_{3}\left(10 \%\right.$ aq soln), $\mathrm{NaHCO}_{3}$ (sat aq soln), and brine, and then dried and filtered. The organic layers were cooled to $-40{ }^{\circ} \mathrm{C}$, and chlorine gas (16 g) was bubbled through the reaction solution at a rate such that the internal temperature of the reaction solution never rose above $-10{ }^{\circ} \mathrm{C}$. After $4 \mathrm{~h}$ the reaction flask was warmed to $\mathrm{rt}$, and the $\mathrm{CH}_{2} \mathrm{Cl}_{2}$ was distilled off at atmospheric pressure. The residue was then further distilled $\left(64-67^{\circ} \mathrm{C}\right.$ at aspirator pressure) through a distillation head containing a $4 \mathrm{~cm}$ Vigreaux column to afford $1(12.3 \mathrm{~g}, 42.3 \%)$ as a light yellow oil with the spectral data corresponding to the literature report: ${ }^{1} \mathrm{H}$ NMR (400 $\mathrm{MHz}) \delta 1.40{ }^{1}$

The sulfinyl chloride was stored at $-30{ }^{\circ} \mathrm{C}$ as a $1.5-2.0 \mathrm{M}$ solution in toluene.

\section{General procedure for the enantioselective formation of sulfinate esters (2,}

14, 15a-e): A solution of proton sponge (128 mg, $0.600 \mathrm{mmol}, 2.5$ equiv), alcohol (1.20

mmol, 5.0 equiv), and internal standard, 2,6-dimethoxytoluene (36.5 mg, $0.240 \mathrm{mmol})$, in THF (1.10 mL, final volume $1.20 \mathrm{~mL}, 0.20 \mathrm{M})$ was prepared and $60.0 \mu \mathrm{L}$ of the solution was transferred to a $500 \mu \mathrm{L}$ vial containing the appropriate catalyst (1-10 mol \%). The vial was cooled to $-78{ }^{\circ} \mathrm{C}$ and sulfinyl chloride $1(7.90 \mu \mathrm{L}, 0.012 \mathrm{mmol}, 1.52 \mathrm{M})$ was added as a solution in toluene over a period of $5 \mathrm{~min}$. At the indicated time, $0.25 \mathrm{~mL}$ of $\mathrm{NEt}_{3} / \mathrm{CD}_{3} \mathrm{OD}\left(0.20 \mathrm{~mL}\right.$ of $\mathrm{NEt}_{3} / 10 \mathrm{~g}$ of $\left.\mathrm{CD}_{3} \mathrm{OD}\right)$ was added to quench any remaining $\mathbf{1}$ and the mixture was transferred to an NMR tube containing $1.00 \mathrm{~mL}$ of $\mathrm{CDCl}_{3}$. After yield determination, the solvents were removed in vacuo and the residue was diluted with 
hexanes (ca. $1.5 \mathrm{~mL}$ ) and filtered for HPLC analysis (For yields and ee, see Tables 1 and 2. See the experimental procedures for the preparation, characterization and chiral HPLC conditions for the racemic sulfinate esters listed below.)

General procedure for the enantioselective formation of sulfinate 2 with 0.5 mol\% of peptide 5: Procedure is the same as above except $600 \mu \mathrm{L}$ of the THF solution is added to a $10 \mathrm{~mL}$ Nalgene Falcon tube containing peptide $\mathbf{6}(17.2 \mu \mathrm{g}, 12.0 \mathrm{nmol})$. After cooling to $-78{ }^{\circ} \mathrm{C}$, sulfinyl chloride $\mathbf{1}$ in toluene (78.9 $\left.\mu \mathrm{L}, 0.120 \mathrm{mmol}, 1.52 \mathrm{M}\right)$ was added over a period of $30 \mathrm{~min}$. At the appropriate time, $2.5 \mathrm{~mL}$ of $\mathrm{NEt}_{3} / \mathrm{CD}_{3} \mathrm{OD}$ $\left(0.20 \mathrm{~mL}\right.$ of $\mathrm{NEt}_{3} / 10 \mathrm{~g}$ of $\left.\mathrm{CD}_{3} \mathrm{OD}\right)$ was added to quench remaining 1 and $0.310 \mathrm{~mL}$ of the mixture was transferred to an NMR tube containing $1.00 \mathrm{~mL}$ of $\mathrm{CDCl}_{3}$.

General procedure for the racemic formation of sulfinate esters $(2,14,15 \mathrm{a}-$ e): A solution of the alcohol $(1.0 \mathrm{~mL}, 9.7 \mathrm{mmol})$ and $\mathrm{NEt}_{3}(2.7 \mathrm{~mL}, 19 \mathrm{mmol})$ in THF $(48 \mathrm{~mL}, 0.20 \mathrm{M})$ was cooled to $-78^{\circ} \mathrm{C}$. Sulfinyl chloride $1(6.0 \mathrm{~mL}, 9.0 \mathrm{mmol}, 1.5 \mathrm{M})$ was added as a solution in toluene, and the reaction vessel was removed from the cold bath. After $1.5 \mathrm{~h}$, the reaction was diluted with EtOAc $(200 \mathrm{~mL})$ and washed with $1 \mathrm{~N}$ $\mathrm{HCl}(50 \mathrm{~mL}), \mathrm{NaHCO}_{3}(50 \mathrm{~mL})$, brine, and then dried and filtered. The EtOAc was removed in vacuo, and the residue was purified via silica gel chromatography to afford pure sulfinate ester.

2-Methylpropanesulfinic acid benzyl ester (2). Reaction of $1.0 \mathrm{~mL}(9.7 \mathrm{mmol})$ of benzyl alcohol according to the general racemic procedure yielded pure $2(1.7 \mathrm{~g}, 83 \%)$ as a colorless oil after chromatography (10\% EtOAc/ hexanes). HPLC (Diacel Chiralpak 
OD column, $96: 04$ hexanes $/$ IPA; $1.0 \mathrm{~mL} / \mathrm{min}) \mathrm{t}_{1}=9.9 \mathrm{~min}, \mathrm{t}_{2}=11.7 \mathrm{~min}$; IR 3065, 2958, 1498, 1391, $1127 \mathrm{~cm}^{-1}$; ${ }^{1} \mathrm{H}$ NMR (400 MHz) 1.18 (s, 9H), 4.97 (1H, $\left.J=12.0 \mathrm{~Hz}\right)$, $5.12(\mathrm{~d}, 1 \mathrm{H}, J=12.0 \mathrm{~Hz}), 7.36(\mathrm{~m}, 5 \mathrm{H}) ;{ }^{13} \mathrm{C}$ NMR $(100 \mathrm{MHz}) 21.7,57.6,75.7,128.3$, 128.5, 128.6, 136.1; Anal. Calcd for $\mathrm{C}_{11} \mathrm{H}_{16} \mathrm{O}_{2} \mathrm{~S}: \mathrm{C}, 62.23$; H, 7.60. Found: $\mathrm{C}, 62.02 ; \mathrm{H}$, 7.71 .

2-Methyl-propane-2-sulfinic acid naphthalen-2-ylmethyl ester (14). Reaction of $0.44 \mathrm{~g}(2.8 \mathrm{mmol})$ of 2-naphthalene-methanol according to the general racemic procedure yielded pure $14(0.58 \mathrm{~g}, 79 \%)$ as a white powder after chromatography (15\% EtOAc/ hexanes). HPLC (Diacel Chiralpak OD column, 96:04 hexanes/ IPA; 1.0 $\mathrm{mL} / \mathrm{min}) \mathrm{t}_{1}=10.7 \mathrm{~min}, \mathrm{t}_{2}=12.5 \mathrm{~min} ; \mathrm{mp} 52-53{ }^{\circ} \mathrm{C} ; \mathrm{IR} 3012,1123 \mathrm{~cm}^{-1} ;{ }^{1} \mathrm{H} \mathrm{NMR}(400$ MHz) $\delta 1.48(\mathrm{~s}, 9 \mathrm{H}), 5.10(\mathrm{~d}, 1 \mathrm{H}, J=11.9), 5.24(\mathrm{~d}, 1 \mathrm{H}, J=11.9), 7.42-7.49(\mathrm{~m}, 3 \mathrm{H})$, 7.76-7.84 (m, 4H); ${ }^{13} \mathrm{C}$ NMR (100 MHz) $\delta 21.6,57.5,71.1,125.9,126.3,126.4,127.5$, 127.7, 128.0, 128.5, 133.1, 133.2, 133.5; Anal. Calcd for $\mathrm{C}_{15} \mathrm{H}_{18} \mathrm{O}_{2} \mathrm{~S}:$ C, 68.67; H, 6.92. Found: C, 68.74; H, 6.93 .

2-Methyl-propane-2-sulfinic acid 4-methoxy-benzyl ester (15a). Reaction of $0.30 \mathrm{~mL}(2.4 \mathrm{mmol})$ of (4-methoxy-phenyl)-methanol according to the general racemic procedure yielded pure 15a $(0.47 \mathrm{~g}, 80 \%)$ as a light yellow powder after chromatography (20\% EtOAc/ hexanes). HPLC (Diacel Chiralpak OD column, 96:04 hexanes/ IPA; 1.0 $\mathrm{mL} / \mathrm{min}) \mathrm{t}_{1}=9.5 \mathrm{~min}, \mathrm{t}_{2}=12.4 \mathrm{~min} ; \mathrm{mp} 26-27{ }^{\circ} \mathrm{C} ; \mathrm{IR} 3063,1614,1515,1124,1033$, $950 \mathrm{~cm}^{-1} ;{ }^{1} \mathrm{H}$ NMR (400 MHz) $\delta 1.10(\mathrm{~s}, 9 \mathrm{H}), 3.72(\mathrm{~s}, 3 \mathrm{H}), 4.86(\mathrm{~d}, 1 \mathrm{H}, J=11.6), 4.99$ $(\mathrm{d}, 1 \mathrm{H}, J=11.6), 6.82(\mathrm{~d}, 1 \mathrm{H}, J=6.8), 7.22(\mathrm{~d}, 1 \mathrm{H}, J=6.8) ;{ }^{13} \mathrm{C}$ NMR $(100 \mathrm{MHz})$ $\delta 21.5,55.1,57.2,70.7,113.8,128.0,130.0,159.7$; Anal. Calcd for $\mathrm{C}_{12} \mathrm{H}_{18} \mathrm{O}_{3} \mathrm{~S}: \quad \mathrm{C}$, 
59.47; H, 7.49. Found: C, 59.51; H, 7.76.

2-Methyl-propane-2-sulfinic acid 4-nitro-benzyl ester (15b). Reaction of 0.55 $\mathrm{g}(3.6 \mathrm{mmol})$ of (4-nitro-phenyl)-methanol according to the general racemic procedure yielded pure 15b $(0.62 \mathrm{~g}, 67 \%)$ as a light yellow powder after chromatography $(60 \%$ EtOAc/ hexanes). HPLC (Diacel Chiralpak OD column, 90:10 hexanes/ IPA; 1.0 $\mathrm{mL} / \mathrm{min}) \mathrm{t}_{1}=9.2 \mathrm{~min}, \mathrm{t}_{2}=10.8 \mathrm{~min} ; \mathrm{mp} 44-45{ }^{\circ} \mathrm{C} ; \mathrm{IR} 3071,2356,1601,1515,1117$, $985 \mathrm{~cm}^{-1} ;{ }^{1} \mathrm{H}$ NMR $(400 \mathrm{MHz}) \delta 1.19(\mathrm{~s}, 9 \mathrm{H}), 5.06(\mathrm{~d}, 1 \mathrm{H}, J=12.8), 5.18(\mathrm{~d}, 1 \mathrm{H}, J=$ 12.8), $7.50(\mathrm{~d}, 1 \mathrm{H}, J=8.8), 8.16(\mathrm{~d}, 1 \mathrm{H}, J=8.8) ;{ }^{13} \mathrm{C} \mathrm{NMR}(100 \mathrm{MHz}) \delta 21.5,57.9$, 69.1, 123.7, 128.3, 143.4, 147.8; Anal. Calcd for $\mathrm{C}_{11} \mathrm{H}_{15} \mathrm{NO}_{4} \mathrm{~S}$ : C, 51.35; H, 5.88; N, 5.44. Found: C, 51.39; H, 5.90; N, 5.42.

2-Methyl-propane-2-sulfinic acid 2,4,6-trimethyl-benzyl ester (15c). Reaction of $0.50 \mathrm{~g}(3.3 \mathrm{mmol})$ of $(2,4,6$-trmethyl-phenyl)-methanol according to the general racemic procedure yielded pure $15 \mathrm{c}(0.69 \mathrm{~g}, 82 \%)$ as a white powder after chromatography (10\% EtOAc/ hexanes). HPLC (Diacel Chiralpak OD column, 99.3:0.7

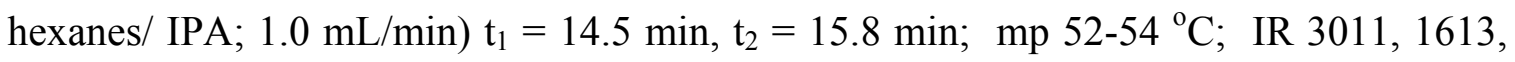
1476, 1124, $933 \mathrm{~cm}^{-1}$; ${ }^{1} \mathrm{H}$ NMR (400 MHz) $\delta 1.14(\mathrm{~s}, 9 \mathrm{H}), 2.28(\mathrm{~s}, 3 \mathrm{H}), 2.38(\mathrm{~s}, 6 \mathrm{H})$, $5.03(\mathrm{~d}, 1 \mathrm{H}, J=11.1), 5.13(\mathrm{~d}, 1 \mathrm{H}, J=11.1), 6.88(\mathrm{~s}, 2 \mathrm{H}) ;{ }^{13} \mathrm{C} \mathrm{NMR}(100 \mathrm{MHz}) \delta$ 19.6, 21.1, 21.6, 57.2, 65.1, 129.1, 129.3, 138.3, 138.7; Anal. Calcd for $\mathrm{C}_{14} \mathrm{H}_{22} \mathrm{O}_{2} \mathrm{~S}$ : C, 66.10; H, 8.72. Found: C, 66.19; H, 8.81.

2-Methyl-propane-2-sulfinic acid benzhydryl ester (15d). Reaction of $0.65 \mathrm{~g}$ 
(3.5 mmol) of benzhydrol according to the general racemic procedure yielded pure 15d $(0.88 \mathrm{~g}, 86 \%)$ as a white powder after chromatography (10\% EtOAc/ hexanes). HPLC (Diacel Chiralpak OD column, 99:01 hexanes/IPA; $1.0 \mathrm{~mL} / \mathrm{min}$ ) $\mathrm{t}_{1}=12.8 \mathrm{~min}, \mathrm{t}_{2}=11.5$ min; mp 72-73 ${ }^{\circ} \mathrm{C}$; IR 3061, 1494, 1124, $959 \mathrm{~cm}^{-1}$; ${ }^{1} \mathrm{H}$ NMR (400 MHz) $\delta 1.25$ (s, 9H), $6.28(\mathrm{~s}, 1 \mathrm{H}), 7.27-7.44(\mathrm{~m}, 10 \mathrm{H}) ;{ }^{13} \mathrm{C} \mathrm{NMR}(100 \mathrm{MHz}) \delta 21.8,57.7,81.8,127.1,127.9$, 128.0, 128.4, 128.5, 128.7, 140.0, 140.6; Anal. Calcd for $\mathrm{C}_{17} \mathrm{H}_{20} \mathrm{O}_{2} \mathrm{~S}$ : C, 70.80; H, 6.99. Found: C, 70.73; H, 7.19.

2-Methyl-propane-2-sulfinic acid phenethyl ester (15e). Reaction of $0.75 \mathrm{~mL}$ (6.3 mmol) of 2-phenyl-ethanol according to the general racemic procedure yielded pure 15e $(1.3 \mathrm{~g}, 91 \%)$ as a clear oil after chromatography (10\% EtOAc/ hexanes). HPLC (Diacel Chiralpak OD column, 96:04 hexanes/ IPA; $1.0 \mathrm{~mL} / \mathrm{min}$ ) $\mathrm{t}_{1}=12.7 \mathrm{~min}, \mathrm{t}_{2}=15.2$ min; IR 3027, 1599, 1496, 1125, $975 \mathrm{~cm}^{-1} ;{ }^{1} \mathrm{H}$ NMR (400 MHz) $\delta 1.15(\mathrm{~s}, 9 \mathrm{H}), 3.03(\mathrm{t}$, $2 \mathrm{H}, J=7.0), 4.18(\mathrm{dt}, 1 \mathrm{H}, J=7.0,10.1), 4.35(\mathrm{dt}, 1 \mathrm{H}, J=7.0,10.1), 7.21-7.38(\mathrm{~m}, 5 \mathrm{H})$; ${ }^{13} \mathrm{C}$ NMR (100 MHz) $\delta 21.6,36.6,57.4,70.1,126.7,128.5,129.0,137.3$; Anal. Calcd for $\mathrm{C}_{12} \mathrm{H}_{18} \mathrm{O}_{2} \mathrm{~S}$ : C, 63.68; H, 8.02. Found: $\mathrm{C}, 63.35 ; \mathrm{H}, 8.20$.

\section{Large scale procedure for the enantioselective formation of sulfinate 14 with}

0.5 mol\% of peptide 5: THF $(11.7 \mathrm{~mL}$, final volume $12.7 \mathrm{~mL}, 0.200 \mathrm{M})$ was added to a $50 \mathrm{~mL}$ teflon vial containing a stir bar, peptide $5(18.3 \mathrm{mg}, 12.7 \mu \mathrm{mol}), 2-$ naphthalenemethanol $(2.00 \mathrm{~g}, 12.7 \mathrm{mmol})$, and proton sponge $(1.36 \mathrm{~g}, 6.37 \mathrm{mmol})$. After cooling the mixture to $-78{ }^{\circ} \mathrm{C}$, sulfinyl chloride $1(1.27 \mathrm{~mL}, 2.55 \mathrm{mmol}, 2.00 \mathrm{M})$ was added as a solution in toluene over a period of $30 \mathrm{~min}$. After $40 \mathrm{~h}, 20 \mathrm{~mL}$ of $\mathrm{MeOH}$ 
and $0.25 \mathrm{~mL}$ of $\mathrm{Et}_{3} \mathrm{~N}$ were added and the reaction solution was allowed to warm to rt. The mixture was diluted with $150 \mathrm{~mL}$ of EtOAc: hexanes $(2: 1)$, and the organic layer were washed with $40 \mathrm{~mL}$ of a $10 \%$ citric acid solution. The aqueous layer was back extracted with $50 \mathrm{~mL}$ of EtOAc: hexanes $(2: 1)$, and the combined organic extracts were washed with brine $(50 \mathrm{~mL})$, dried, and concentrated in vacuo. The residue was dissolved in $3 \mathrm{~mL}$ of $\mathrm{CH}_{2} \mathrm{Cl}_{2}$ followed by a $2 \mathrm{~mL}$ hexane rinse and was passed through a silica plug $(4.0 \times 6.5 \mathrm{~cm})$ eluting with $15 \%$ EtOAc: hexanes. The resulting solution was concentrated in vacuo and the solid residue was recrystallized twice from heptanes $(1.00 \mathrm{~mL} / 0.100 \mathrm{~g}$ of sulfinate ester) with cooling to $8{ }^{\circ} \mathrm{C}$ over 12 hours for each recrystallization to afford (S)-14 as short clear needles $(0.410 \mathrm{~g}, 61.2 \%, 99.2 \%$ ee). HPLC (Diacel Chiralpak OD column, 96:04 hexanes/ IPA; $1.0 \mathrm{~mL} / \mathrm{min}) \mathrm{t}[(S)-14]=10.7 \mathrm{~min}, \mathrm{t}[(R)-\mathbf{1 4}]=12.5 \mathrm{~min}$.

\section{Determination of the absolute stereochemistry of sulfinate ester 14: Sulfinate} ester $(S)$-14 (50 mg, $0.19 \mathrm{mmol}, 99.2 \%$ ee), was added to a flame dried 1-dram vial containing THF $(1.0 \mathrm{~mL}, 0.20 \mathrm{M})$, and the mixture was cooled to $-78{ }^{\circ} \mathrm{C}$. $\mathrm{PhLi}(0.32$ $\mathrm{mL}, 0.57 \mathrm{mmol}, 1.8 \mathrm{M}$ ) was added dropwise, and the reaction mixture was stirred for $2 \mathrm{~h}$. After the addition of $\mathrm{AcOH}(0.60 \mathrm{~mL}, 1 \mathrm{M}$ in THF), the mixture was warmed to rt, diluted with EtOAc $(5 \mathrm{~mL})$, and washed with brine. The aqueous layer was washed with EtOAc $(3 \times 10 \mathrm{~mL})$, and the combined organic extracts were dried and concentrated in vacuo. The resulting residue was purified by column chromatography (40:60 to 50:50 EtOAc: hexanes) to afford ( $R$ )-tert-butyl phenyl sulfoxide (31 mg, 90\%, 99.2\% ee) with spectral data corresponding to the literature report: ${ }^{2}$ HPLC (Diacel Chiralpak AS 
column, 90:10 hexanes/ ethanol; $1.0 \mathrm{~mL} / \mathrm{min}) \mathrm{t}(S)=7.2 \mathrm{~min}, \mathrm{t}(R)=9.5 \mathrm{~min} ;{ }^{1} \mathrm{H} \mathrm{NMR}$ (400 MHz) $\delta 1.14(\mathrm{~s}, 9 \mathrm{H}), 7.51-7.52(\mathrm{~m}, 3 \mathrm{H}), 7.61-7.63(\mathrm{~m}, 2 \mathrm{H})$.

${ }^{1}$ Bleeker, I. P.; Engberts, J. B. F. N. J. Org. Chem., 1981, 46, 1012-1014.

${ }^{2}$ Cogan, D.A.; Liu, G.; Kim, K.; Backes, B. J.; Ellman, J. A. J. Am. Chem. Soc. 1998, 120, 8011-8019. 